\title{
Transfer Pricing Aggressiveness and Corporate Governance: Indonesia's Evidence
}

\author{
Dewi Kartika Sari ${ }^{1 *}$ \\ ${ }^{1}$ Accounting and Audit Laboratory, Vocational Education Program, \\ Universitas Indonesia \\ *Email: dewi.kartika@gmail.com
}

\begin{abstract}
This study aimed at developing the transfer pricing aggressiveness measurement and empirically testing the effect of the corporate governance (CG) mechanism on the aggressiveness of transfer pricing. The transfer pricing aggressiveness measurement was developed using PMK No. 213/PMK.03/2016 and regulation of BAPEPAM-LK Number VIII.G.7 (2012) as references. The sample used in this research is 100 companies with the largest market capitalization listed on the Indonesia Stock Exchange (BEI) in the period 2012-2014. The results show that the developed transfer pricing aggressiveness index can be used to measure aggressiveness of transfer pricing. However, this research could not provide support that CG can reduce the aggressiveness of transfer pricing.
\end{abstract}

Keywords: transfer pricing aggressiveness, corporate governance, related party transaction

\section{Introduction}

With the advancement of globalization and technology, business is run without borders. This condition, while favorable for multinational companies, can harm the company's origin country. It is said to be detrimental to a company's home country because the complexity of inter-state regulations can create loopholes and mismatches between regulations that allow multinational companies to exploit these regulatory differences (Jones, Temouri, \& Cobham, 2018). One example is the tax rate differences between countries. This difference may encourage multinational companies to carry out tax planning policies that allow companies to minimize the amount of tax paid by shifting the profit to related parties. Profit shifted from companies located in countries with high tax rates to related parties in countries with low tax rates is done through the transfer pricing mechanism.

The transfer pricing scheme conducted by multinational companies may be detrimental to the origin country, because, if the company shifts its profit to a related party located in another country, then the government of the origin country will lose the potential tax revenue on the shifted profit. When a company uses transfer pricing without arm-length transactions extensively, it is said to be engaged in aggressive transfer pricing activities (Richardson, Taylor, \& Lanis, 2013).

In response to the possible profit shifting behavior of multinational companies, policy makers around the world have agreed to control this action (Dowd, Landefeld, \& Moore, 2017). G20 member states and member countries of the Organization for Economic Corporation and Development (OECD) have joined the Base Erosion and Profit Shifting Project (BEPS). The BEPS project aims to ensure that international tax regulations applied by its member countries do not facilitate the shifting of business profits from the actual location of the economic activity (OECD, 2017).

The BEPS project consists of 15 actions, one of which is the uniformity of transfer pricing documentation, which aims to increase transparency of the company's transfer pricing actions (BEPS action 13). As a manifestation of participation in this international agreement, the Government of the Republic of Indonesia has issued a regulation of Finance Minister of PMK No.213/PMK.03/2016, regulating the types of documents and/or additional information that must be kept by taxpayers conducting transactions with related parties and management procedures. This rule aims to reduce tax-avoidance actions that can be done by multinational companies through transfer pricing schemes.

Studies on the challenges of tax inspectors in Indonesia that examine the transfer pricing of intangible assets performed by multinational companies in Indonesia show that tax inspectors in Indonesia have difficulty in checking the transfer pricing transactions (Muhammadi, 2016). The difficulty proving that companies engage in the practice of transfer pricing make it hard for the government to predict the losses caused by the practice of transfer pricing. However, the Directorate General of Taxation predicts the potential loss of tax revenue due to transfer pricing practices can reach trillions of Rupiah (Observation \& Research of Taxation, 2012). Therefore, it would be interesting to develop a measurement of transfer pricing aggressiveness as well as investigate what factors influence a company's transfer pricing aggressiveness. 
Research in Australia on the determinants of transfer pricing aggressiveness shows that firm size, profitability, leverage, intangible assets, and multinationalism are significantly associated with aggressiveness of transfer pricing (Richardson et al., 2013). In Indonesia, it has been found that firm size and leverage are positively associated with aggressive transfer pricing, but intangible assets and multinationalism are negatively related. In Indonesia, it has also been found that the profitability and use of tax-haven country are not related to transfer pricing aggressiveness (Waworuntu \& Hadisaputra, 2016).

Corporate governance $(\mathrm{CG})$ is a mechanism that can reduce the information asymmetry between internal and external parties (La Porta, Lopez-de-Silanes, Shleifer, \& Vishny, 2000). The role of oversight of good CG can be a mechanism that ensures companies transparently report transactions. Thus, it is expected to reduce the possibility of unfair transfer pricing activities.

Thus far, no studies have examined the effect of CG mechanisms on transfer pricing aggressiveness. Previous research has tested the effects of profitability, leverage, intangible assets, and multinationalism on the transfer pricing aggressiveness (Richardson et al., 2018; La Porta et al., 2000). Previous research has also tried to develop a transfer pricing aggressiveness measurement, such as the measurement index developed by the Australian Taxation Office (Richardson et al., 2018; La Porta et al., 2000). Meanwhile, other earlier studies in Indonesia tended to measure the existence of transfer pricing activities simply by using the existence of related party transaction (RPT) as an indicator of transfer pricing activity, i.e., if there is RPT, then the company is considered to be performing transfer pricing activities (dummy variables) (Ge, Drury, Fortin, Liu, \& Tsang, 2010; Utama, Utama, \& Yuniasih, 2010).

This study sought to provide three contributions. First, it tried to develop a measurement of aggressiveness of transfer pricing in Indonesia by using PMK No.213/PMK.03/2016 and BAPEPAM-LK regulation Number VIII.G.7 (2012) as references. Second, it continued previous studies (Richardson et al., 2018; La Porta et al., 2000) on what factors influence the aggressiveness of transfer pricing, by adding the CG mechanism as one of the factors affecting the aggressiveness of transfer pricing. Third, in addition to testing, this study also tried to measure the aggressiveness of transfer pricing by using RPT amount. Compared with the dummy variable, the amount of RPT is expected to better reflect the company's transfer pricing aggressiveness. Based on the above explanation, the purpose of this study was to develop the transfer pricing aggressiveness measurement and to examine the effect of CG mechanism on company's transfer pricing aggressiveness.

The next section describes the literature review and hypothesis formulation. Then, the data source and empirical research model are presented. After that, the test results are discussed. Finally, the conclusions and implications of this study are presented.

\section{2 . Literature Review and Hypothesis Development}

\subsection{Transfer Pricing Regulations in Indonesia}

Related to transfer pricing activities, the Government of the Republic of Indonesia has issued several rules aimed at restricting or making transparent information related to such activities. The regulations in question are DGT Regulation No. PER-32/PJ/2011, PMK No.213/PMK.03/2016 and Regulation of the Capital Market and Financial Institution Supervisory Agency (BAPEPAM-LK) Number VIII.G.7 (2012).

DGT Regulation No. PER-32/PJ/2011 stipulates the application of fairness principle and business practice in the transaction between taxpayer with the related party. In the regulation, it is stated that the tax payer who transacts with related parties must apply the principle of fairness and business practice. This principle states that the price or profit of a reasonable transaction is determined by the market forces, thus the transaction is said to be fair if using fair market value.

Regulation PMK.No.213/PMK.03/2016 regulates the types of documents and/or additional information that must be kept by taxpayers conducting transactions with related parties and management procedures. This regulation was issued in line with the recommendations of the OECD on the final report on Transfer Pricing Documentation and Country-by-Country Reporting-Action 13 (also called BEPS Action 13). Based on PMK.No.213/PMK.03/2016, the tax payer who is obliged to carry out the transfer pricing document is the tax payer who performs affiliate transactions with: (1) the value of gross circulation in the previous tax year in a year more than Rp.50 billion; (2) the value of affiliate transactions in the previous tax year in one tax year of more than Rp.20 billion for the transaction of tangible goods; more than Rp.5 billion for each service provision, interest payment, intangible goods utilization, or other transactions; or affiliates residing in a country or jurisdiction with an income tax rate lower than the rate of income tax as an income tax law; and (3) the tax payer is a parent of a business group having consolidated gross turnover in the taxable year concerned at least Rp.11 trillion.

Regulation of the Capital Market and Financial Institution Supervisory Agency (BAPEPAM-LK) Number VIII.G.7 (2012), which regulates the presentation and disclosure of financial statements of issuers or public 
companies, specifies what components of financial statements should be disclosed in case of transactions with related parties (RPT). Previous research has summarized this rule and indicates that there are ten components of RPT to be disclosed by the company (Utama \& Utama, 2014): (1) the amount of RPT in assets and liabilities; (2) the percentage of the RPT in the asset against the total value of the asset and the percentage of the RPT in the liability to the total value of the liability; (3) for RPT with the nearest person or member valued at more than Rp. 1 billion and/or more than $0.5 \%$ of paid up capital for transactions with related entities, the company should discloses the value of the transaction, identity and relationship with transfers; (4) explanation of RPT not related to the company's main business activity; (5) the amount of debt or receivable transactions with related parties that do not arise from the company's main business activities; (6) the nature of the relationship, type, and element of the transaction; (7) pricing policy for RPT; (8) the transaction terms of the RPT; (9) whether the pricing policy and terminology of the RPT transaction is the same as the transaction with the non-related party; and (10) the reasons and grounds for recognizing the loss of the RPT receivables.

\subsection{Corporate Governance}

CG is a mechanism that aims to maximize shareholder wealth, in which the mechanism is implemented by considering the interests of all stakeholders and obeying government regulations and agreements made with stakeholders (Claessens \& Yurtoglu, 2013).

The OECD in collaboration with the Financial Services Authority (OJK) has launched The New G20/OECD Principles of Corporate Governance. One of the principles contained in CG is transparency and information disclosure (Otoritas Jasa Keuangan, 2015). If CG is implemented well, then this mechanism can reduce the information asymmetry between the internal and external parties (La Porta et al., 2000). Board members with financial expertise, as one of the CG mechanisms, have been found to have a negative relationship with high-level corporate tax-avoidance measures (Armstrong, Blouin, \& Jagolinzer, 2015). It has been found that a good CG application can weaken the positive relationship between tax-avoidance measures and the number of RPTs (Sari, Utama, \& Rossieta, 2017). Therefore, the implementation of good CG is expected to reduce the company's transfer pricing aggressiveness. Based on these arguments, this research proposes an alternative hypothesis as follows:

H1: Corporate governance is negatively related to the company's transfer pricing aggressiveness.

\section{Research Method}

\subsection{Sample}

The sample used in this research is 100 companies with the largest market capitalization listed on the Indonesia Stock Exchange (BEI) in the period 2012-2014. This period was chosen because the ASEAN CG scorecard data were issued by the Indonesian Institute for Corporate Directorship (IICD) only for the period 2011-2014, and there were several measurements of variables in this study that required prior period data (t-1). Financial data were obtained from the portal data www.idx.co.id or taken directly from the portal company concerned. As for CG data, this study used the CG scorecard data issued by IICD.

\subsection{Research Model}

To test the proposed hypothesis, i.e., to test the relationship between CG and aggressiveness of transfer pricing, this research used the research model equation as follows:

$$
T P A G_{i t}=\beta_{0}+\beta_{1} C G_{i t}+\beta_{2} S_{Z Z E_{i t}}+\beta_{3} P R O F I T_{i t}+\beta_{4} L E V_{i t}+\beta_{5} M U L T I_{i t}+\varepsilon_{i t}
$$

where

TPAG = transfer pricing aggressiveness rate of firm $i$ in year $t$.

$C G=$ ASEAN CG corporate scorecard value of firm $i$ in year $t$.

SIZE = natural logarithm value of total assets of firm $i$ in year $t$.

PROFIT = natural value of logarithm of profit before tax of firm $i$ in year $t$.

$L E V \quad=$ leverage value (long-term debt divided by total assets) of firm $i$ in year $t$.

MULTI = number of subsidiaries or parent company $i$ in year $t$ domiciled in overseas.

If the hypothesis is proved, then this study expects value $\beta_{1}$ has a negative direction. The stronger CG implementation is expected to reduce the company's transfer pricing activities. 


\subsection{Variable Measurement}

\subsubsection{Dependent Variable}

The dependent variable used in this study represents the transfer pricing aggressiveness (TPAG) performed by the company. The developed index refers to PMK.No.213/PMK.03/2016 and BAPEPAM-LK Regulation No.VIII.G.7 (2012). This is similar to previous research (Richardson et al., 2013) that generated the transfer pricing index under the 2005 ATO rules and the Australian Securities and Investment Commission regulations. The index components developed in this study are as follows:

(1) The value of gross circulation in the previous tax year in one year is more than Rp.50 billion.

(2) The value of the previous year's affiliate transactions in a tax year is more than Rp.20 billion for the transaction of tangible goods.

(3) The value of the previous year's affiliate transactions in a tax year is more than Rp.5 billion for each of the provision of services, interest payments, the use of intangible goods, or other transactions.

(4) Affiliates are in a country or jurisdiction with a lower income tax rate than the rate of income tax as the income tax law.

(5) A parent entity of a business group has consolidated gross turnover in the relevant tax year of at least Rp.11 trillion.

(6) The business does not disclose pricing policy for RPT.

(7) The business does not disclose that the pricing and terms policy of the RPT transaction is the same as the transaction with the arm's length justification.

(8) The business does not disclose the reasons and grounds for the recognition of the loss of accounts receivable from the RPT.

Following previous studies (Richardson et al., 2018; Armstrong et al., 2015), in calculating the TPAG, the index of this study gives a value of 1 for each component of the index above, then sums the index component scores and divides them by the maximum total score applicable to the firm, and finally multiplies it by $100 \%$.

This study did not include any other components that should be disclosed by BAPEPAM-LK Regulation No.VIII.G.7 (2012) because, according to the data analysis, all sample companies have made such disclosure. Disclosures not included in the index are: (1) the amount of RPT in assets and liabilities; (2) the percentage of the RPT in the asset against the total value of the asset and the percentage of the RPT in the liability to the total value of the liability; (3) for RPT with the nearest person or member valued at more than Rp.1 billion and/or more than $0.5 \%$ of paid up capital for transactions with related entities, the company discloses the value of the transaction, and identity of and relationship with transfers; (4) explanation of RPT not related to the company's main business activity; (5) the amount of debt or receivable transactions with related parties that do not arise from the company's main business activities; and (6) the nature of the relationship, type, and element of the transaction.

\subsubsection{Independent Variable}

CG measurements in this study used the ASEAN CG scorecard issued by IICD. ASEAN CG scorecard values are derived from measuring the five $\mathrm{CG}$ components present in the OECD principle: right of shareholders, equitable treatment, the role of stakeholders, disclosure and transparency, and responsibilities of the board. IICD analyzes the above five CG components for 100 companies with the highest 100 market capitalization values for a given financial reporting period. At the time this research was conducted, IICD had released ASEAN CG scorecard data for the 2011-2014 financial reporting period.

\subsubsection{Control Variable}

Control variables used in this study are variables that have been shown to affect TPAG. The variables in question are SIZE, PROFIT, LEV, and MULTI. Firm size (SIZE) can affect the aggressiveness of transfer pricing because large firms (rather than small firms) tend to have more transactions with related parties, thus there is a high probability of transfer pricing activities, more tax advantages than lease transactions or financing agreements derived from complex transactions. Thus, large companies are better able to take advantage of tax arbitration that may arise from different tax jurisdictions (Richardson et al., 2013). Previous research has also found that large companies tend to be more able to participate in aggressive transfer pricing agreements (AlEryani, Alam, \& Akhter, 2017). Thus, it is suspected that as SIZE increases, TPAG will also increase. 
Firms with good profitability (PROFIT) tend to conduct transactions or schemes designed to avoid taxes (Rego, 2003). For example, high-profit companies such as Apple and Google are able to allocate company profits in state jurisdictions that have low tax rates (Womack \& Drucker, 2011; Dughigg \& Kocienienwski, 2012). Thus, it is assumed that firms with greater PROFIT will also have more aggressive transfer pricing.

Firms with high leverage rates tend to prefer to take advantage of using debt as a source of corporate finance (Rego, 2003; Dyreng, Hanlon, \& Maydew, 2008). Multinational companies also typically make funding to members of a business group through the distribution of debt and share capital (Richardson et al., 2013). Thus, it is possible for companies that have a high leverage rate to perform aggressive transfer pricing.

This study also controlled multinationalism, because multinational companies regularly conduct effective tax planning within their business groups. Thus, they can use the differences in tax rates of their subsidiaries through aggressive transfer pricing. Multinational companies also tend to be more successful in avoiding domestic tax. Thus, it is assumed that multinationalism is positively related to the aggressiveness of transfer pricing (Rego, 2003).

\section{Research Results and Discussion}

\subsection{Sample Selection Results}

The sample criteria used in this study were as follows: (1) the companies with the 100 largest market capitalization during 2012-2014, which are included in the CG scorecard data issued by IICD; (2) always included in IICD data; (3) excluding the financial industry; (4) does not have a negative profit value; and (5) has a subsidiary or parent abroad.

Table 1. Summary of Sample Selection Procedure

\begin{tabular}{lcc}
\hline \multicolumn{1}{c}{ Sample Criteria } & $\begin{array}{c}\text { Number of } \\
\text { Companies }\end{array}$ & $\begin{array}{c}\text { Number of } \\
\text { Observations }\end{array}$ \\
\hline Included in IICD data (2011-2014) & 131 & 393 \\
Less: & & $(183)$ \\
$\quad$ Not always included in IICD data & $(17)$ & $(51)$ \\
Included in the financial industry & & $(10)$ \\
Has a negative profit value & & $(34)$ \\
\hline Has no overseas subsidiary or parent & & $(115)$ \\
\hline Number of final observations & & \\
\hline
\end{tabular}

Source: data processed

The financial industry was excluded from the sample because the composition of their financial statements is different from other industries, so they cannot be compared. Companies that have negative earnings values were excluded from the sample data because, according to previous research, companies that tend to take aggressive transfer pricing are those that have high profitability (Rego, 2003). Companies that do not have subsidiaries or overseas parent were also excluded from the sample because only multinational companies can use transfer pricing schemes for tax purposes. However, since the preliminary sample data are companies that belong to the group of 100 highest capitalization markets, there could be the possibility of sample bias. Based on the criteria mentioned above, finally, this research used 115 observations. To ensure the data are normally distributed, winsorizing was performed by taking the upper and lower limits as three times the standard deviation of the mean value. A summary of sample selection can be seen in Table 1.

\subsection{Descriptive Statistics}

The descriptive statistical analysis aimed to provide a simple overview of the data and the results of the research conducted. Table $2 \mathrm{~A}$ shows that the average value of the company's TPAG is $70.54 \%$, the minimum value is $37.5 \%$ and the maximum is $100 \%$. This indicates that the average sample company has the potential to aggressively transfer pricing. The $C G$ value shows that the average CG scorecard of the sample company is 57.78 , the minimum value is 31.24 , and the maximum value is 90.90 . This shows the strength of the application of $C G$ mechanisms in the sample companies varies. 
Table 2. Descriptive Statistics and Correlation Analysis

\begin{tabular}{|c|c|c|c|c|c|c|}
\hline \multicolumn{7}{|c|}{ Panel A: Descriptive Statistics } \\
\hline & Mean & Maximum & Minimum & Std. Dev. & Jarque-Bera & Prob. \\
\hline$T P A G$ & $70.54 \%$ & $100 \%$ & $37.50 \%$ & $16.24 \%$ & 2.71 & 0.26 \\
\hline$C G$ & 57.78 & 90.90 & 31.24 & 11.51 & 1.28 & 0.53 \\
\hline SIZE & 30.55 & 33.09 & 28.21 & 0.95 & 1.87 & 0.39 \\
\hline PROFIT & 28.24 & 30.04 & 26.42 & 1.04 & 3.68 & 0.16 \\
\hline$L E V$ & 0.45 & 0.78 & 0.14 & 0.18 & 5.55 & 0.06 \\
\hline MULTI & 3.37 & 9:00 & 1.00 & 2.61 & 15.17 & 0.00 \\
\hline \multicolumn{7}{|c|}{ Pearson Correlation } \\
\hline & $T P A G$ & $C G$ & SIZE & PROFIT & $L E V$ & MULTI \\
\hline$T P A G$ & 1 & & & & & \\
\hline$C G$ & -0.085 & 1 & & & & \\
\hline SIZE & $0.203 * *$ & $0.292 * * *$ & 1 & & & \\
\hline PROFIT & -0.036 & $0.330 * * *$ & $0.630 * * *$ & 1 & & \\
\hline$L E V$ & 0.061 & -0.060 & 0.037 & $0.256 * * *$ & 1 & \\
\hline MULTI & $0.261 * * *$ & 0.091 & $0.240 * * *$ & 0.003 & 0.022 & 1 \\
\hline \multicolumn{7}{|l|}{$\mathrm{N}=115$} \\
\hline \multicolumn{7}{|c|}{$\begin{array}{l}\text { TPAG = aggressiveness index of pricing transfer, ranges from } 0-100 \% ; C G=\mathrm{CG} \text { scorecard; SIZE } \\
=\text { the natural value of the logarithm of total assets; PROFIT = natural value of logarithm of profit } \\
\text { before tax; } L E V=\text { value of long-term debt divided by total assets; } M U L T I=\text { number of subsidiaries } \\
\text { or holding companies domiciled overseas. } \\
\text { Where: } * * * \text { significant } 1 \% ; * * \text { significant } 5 \% ; * 10 \% \text { significant. }\end{array}$} \\
\hline
\end{tabular}

Source: data processed

If we look at the SIZE and PROFIT values, the results of the descriptive statistics show that the size and profitability of the company in the sample is almost homogeneous, that is, large companies with good profitability. Meanwhile, if we look at the $L E V$ value, it is seen that the leverage of the sample company varies, with a minimum value of 0.14 and a maximum of 0.78 . The last descriptive statistic shows that the multinationalism (MULTI) value of the number of subsidiaries or overseas parent companies of the sample has differs greatly, with a minimum value of 1 and a maximum of 9 overseas parents or subsidiaries, and is spread abnormally.

The results of the correlation test in Table 2B show that the average relation between variables has a small value, except for the relationship between SIZE and PROFIT, which have the correlation value of 0.63 . However, this is not expected to cause serious correlation problems. Table $2 \mathrm{~B}$ also shows the presence of $C G$ and PROFIT indications relating negatively to TPAG, whereas SIZE, LEV, and MULTI variables are positively associated with $T P A G$. However, this still needs to be tested further.

\subsection{Regression Analysis}

The result of regression testing in Table 3 shows that TPAG can be a measure of aggressiveness of transfer pricing. This is shown by the F-stat model with a value of 3.52 and probability $0.005(\alpha=1 \%)$.

Table 3 also shows that CG practice does not significantly influence the TPAG. Thus, $\mathrm{H}_{1}$ is not supported. This is similar to a previous study, which found that CG practices are incapable of influencing the number of a related party's transactions (Utama, 2015). This is allegedly because CG practice has not been implemented effectively, but only to comply with the regulations set by the government.

Related to control variables, it can be seen that variables SIZE and MULTI have a positive and significant influence on the TPAG. These findings support the findings of previous studies (Richardson et al., 2013). However, surprisingly, PROFIT variable also shows a significant influence, but has a coefficient direction contrary to the prediction, i.e., a negative direction. This indicates that the control variables tested have not been consistently shown to affect the TPAG. 
Table 3. Transfer Pricing Aggressiveness and Corporate Governance

\begin{tabular}{|c|c|c|c|c|}
\hline \multicolumn{5}{|c|}{$T P A G_{i t}=\beta_{0}+\beta_{1} C G_{i t}+\beta_{2}$ SIZE $_{i t}+\beta_{3} P R O F I T_{i t}+\beta_{4} L E V_{i t}+\beta_{5} M_{U L T I}+\varepsilon_{i t}$} \\
\hline Variabel & Arah Prediksi & Koefisien & $t$-value & Prob. \\
\hline Intercept & & 0.119 & 0.235 & 0.815 \\
\hline$C G$ & $(-)$ & -0.001 & -0.977 & 0.331 \\
\hline SIZE & $(+)$ & 0.059 & 2.783 & $0.006 * * *$ \\
\hline PROFIT & $(+)$ & -0.039 & -2.031 & $0.045 * *$ \\
\hline$L E V$ & $(+)$ & -0.109 & -1.307 & 0.194 \\
\hline MULTI & $(+)$ & 0.011 & 1.821 & $0.071 *$ \\
\hline $\operatorname{Adj.} R^{2}(\%)$ & \multicolumn{4}{|l|}{$9,97 \%$} \\
\hline $\begin{array}{l}\text { F-Stat. } \\
\text { Prob. (F-stat. })\end{array}$ & \multicolumn{4}{|l|}{$\begin{array}{l}3,525 \\
(0,005) * * *\end{array}$} \\
\hline \multicolumn{5}{|l|}{$\mathrm{N}=115$} \\
\hline \multicolumn{5}{|c|}{$\begin{array}{l}\text { TPAG = transfer pricing aggressiveness index, ranges from } 0-100 \% ; C G=\text { CG scorecard; SIZE } \\
=\text { the natural value of the logarithm of total assets; PROFIT = natural value of logarithm of profit } \\
\text { before tax; LEV = value of long-term debt divided by total assets; MULTI = number of } \\
\text { subsidiaries or holding companies domiciled overseas. } \\
\text { Where: *** significant } 1 \% \text {; } * * \text { significant } 5 \% ; * 10 \% \text { significant. }\end{array}$} \\
\hline
\end{tabular}

Source: data processed

\subsection{Additional Test}

To measure the aggressiveness of transfer pricing, this study attempted to use the RPT amount as an indicator of TPAG. Compared to the RPT dummy variable (Ge et al., 2010; Utama et al., 2010), the use of RPT amount is expected to better reflect the degree of company's TPAG.

Referring to the results of previous studies (Utama \& Utama, 2014), this study measured RPTs based on the RPT disclosure group, the RPT associated with the asset group (RPTA) and the RPT associated with the liability group (RPTL). This study did not test the size of $R P T$ based on sales (RPTS) and expenses (RPTE), because based on sample analysis, many companies do not disclose the value of RPTS and RPTE. Distributions of RPTA, RPTL, RPTS, and RPTE disclosure can be seen in Table 4.

Table 4 shows that the disclosure of the company's RPT mostly comprises RPTA and RPTL, respectively, $88.43 \%$ and $81.48 \%$ of total observations, while the data distributions of RPTS and RPTE, respectively, represent only $68.98 \%$ and $65.28 \%$.

Table 4. Distribution of RPT data in observation

\begin{tabular}{|c|c|}
\hline Distribution of RPT transactions & Number of \% observations \\
\hline RPTA & $88.43 \%$ \\
\hline RPTL & $81.48 \%$ \\
\hline RPTS & $68.98 \%$ \\
\hline RPTE & $65.28 \%$ \\
\hline
\end{tabular}

This additional test was performed by re-examining the regression Equation (1) but using $R P T A$ and $R P T L$ as TPAG measurements, replacing the aggressive transfer pricing index. The RPTA value was derived from dividing the total RPTA value by the total asset value. The value of $R P T L$ is the total value of $R P T L$ divided by the total value of liabilities (Utama \& Utama, 2014). Regression testing results can be seen in Table 5.

Table 5. Transfer Pricing Aggressiveness and Corporate Governance

\begin{tabular}{|c|c|c|c|}
\hline \multicolumn{4}{|c|}{$T P A G_{i t}=\beta_{0}+\beta_{1} C G_{i t}+\beta_{2} S I Z E_{i t}+\beta_{3} P R O F I T_{i t}+\beta_{4} L E V_{i t}+\beta_{5} M_{U L T I}+\varepsilon_{i t}$} \\
\hline Variables & $\begin{array}{c}\text { Prediction } \\
\text { Direction }\end{array}$ & RPTA & $R P T L$ \\
\hline Intercept & & $\begin{array}{l}-0.027 \\
(0,773)\end{array}$ & $\begin{array}{l}-0.041 \\
(0,743)\end{array}$ \\
\hline$C G$ & $(-)$ & $\begin{array}{c}0.001 \\
(0,009) * * *\end{array}$ & $\begin{array}{c}0.001 \\
(0,057)^{*}\end{array}$ \\
\hline
\end{tabular}




\begin{tabular}{|c|c|c|c|}
\hline SIZE & $(+)$ & $\begin{array}{c}0.003 \\
(0,522) \\
\end{array}$ & $\begin{array}{c}0.000 \\
(0,921)\end{array}$ \\
\hline PROFIT & $(+)$ & $\begin{array}{l}-0.002 \\
(0,566)\end{array}$ & $\begin{array}{c}0.001 \\
(0,898)\end{array}$ \\
\hline$L E V$ & $(+)$ & $\begin{array}{l}-0.015 \\
(0,389) \\
\end{array}$ & $\begin{array}{c}0.005 \\
(0,796) \\
\end{array}$ \\
\hline MULTI & $(+)$ & $\begin{array}{c}0.001 \\
(0,389) \\
\end{array}$ & $\begin{array}{c}0.000 \\
(0,883)\end{array}$ \\
\hline $\operatorname{Adj.} R^{2}(\%)$ & & $5,48 \%$ & $0,23 \%$ \\
\hline $\begin{array}{l}\text { F-Stat. } \\
\text { Prob. }(F \text {-stat. })\end{array}$ & & $\begin{array}{c}2,32 \\
(0,047)^{* *}\end{array}$ & $\begin{array}{c}1,05 \\
(0,389) \\
\end{array}$ \\
\hline \multicolumn{4}{|l|}{$\mathrm{N}=115$} \\
\hline \multicolumn{4}{|c|}{$\begin{array}{l}T P A G=\text { transfer pricing aggressiveness measured using RPTA and RPTL; CG = CG scorecard; } \\
S I Z E=\text { the natural value of the logarithm of total assets; PROFIT = natural value of logarithm of } \\
\text { profit before tax; } L E V=\text { value of long-term debt divided by total assets; } M U L T I=\text { number of } \\
\text { subsidiaries or holding companies domiciled overseas. } \\
\text { Where: } * * * \text { significant } 1 \% ; * * \text { significant } 5 \% ; * 10 \% \text { significant. }\end{array}$} \\
\hline
\end{tabular}

Source: data processed

Table 5 shows that, if aggressiveness of pricing transfer is measured using RPTA and RPTL, the $C G$ variables appear to affect $T P A G$ positively and significantly, thus it is indicated that strong $C G$ implementation will increase the aggressiveness of transfer pricing by the company. This is contrary to the logic and results of previous literature. Considering the statistical value of other variables that are not significant, and the small adjusted $R^{2}$ and $F$-stat value, it is assumed that the model tested is not a good model. Thus, it cannot be interpreted further. Compared with Table 3 results, it can be seen that the model using the TPAG index is better for measuring the aggressiveness of transfer pricing.

\section{Conclusion}

This study aimed to develop the TPAG measurement as well as empirically test the effect of CG mechanism on the aggressiveness of transfer pricing. The TPAG measurement was developed using PMK No.213/PMK.03/2016 and BAPEPAM-LK regulation Number VIII.G.7 (2012) as references.

This research provides three contributions. First, this research developed the TPAG measurement by using PMK No.213/PMK.03/ 016 and BAPEPAM-LK regulation Number VIII.G.7 (2012) as - references. Second, this research continued the previous research (Richardson et al., 2018; Waworuntu \& Hadisaputra, 2016) on testing whether the CG mechanism applied by the company is also a factor affecting the aggressiveness of transfer pricing. Third, as an additional test, this study measured the aggressiveness of transfer pricing by using RPT amount.

This study moderately indicated that the developed the TPAG index can be used to measure TPAG. However, this research could not provide support that CG can reduce the aggressiveness of transfer pricing.

The results of this study have several implications. First, the TPAG index developed in this study is expected to be useful for researchers. Hopefully, there will be further studies that can prove the reliability of this developed TPAG index. Second, the test results show that the $C G$ monitoring function cannot reduce the transfer pricing activity, providing support for the implementation of PMK No. 213/PMK.03/2016, which would require additional documentation and information related to the related relationship transactions. Finally, the company's results are expected to implement the CG effectively, so that the expected monitoring function of the CG mechanism can deliver maximum results.

This study has several limitations. First, testing was only done on companies among the 100 largest by market capitalization during the observation period. The addition of the number of samples will increase the ability of the research results to be generally accepted. Secondly, robustness test using index developed by previous studies was not performed (Richardson et al., 2013). Robustness test will increase the reliability of test results.

\section{Acknowledgment}

I would like to thank Dr. Dewi Martani for her valuable input and also for the Accounting and Audit Laboratory of Vocational Education Program Universitas Indonesia which enabled this research to be conducted. 


\section{References}

Al-Eryani, M. F., Alam, P., \& Akhter, S. H. (1990). Transfer pricing determinants of U.S. multinationals. Journal of International Business Studies, 21(3), 409-425.

Armstrong, C. S., Blouin, J. L., \& Jagolinzer, A. D. (2015). Corporate governance, incentives, and tax avoidance. Journal of Accounting and Economics, 1-17.

Claessens, S., \& Yurtoglu, B. B. (2013). Corporate governance in emerging markets: A survey. Emerging Markets Review, $15,1-33$.

Dowd, T., Landefeld, P., \& Moore, A. (2017). Profit shifting of U.S. multinationals. Journal of Public Economics, 148, 113.

Dughigg, D., \& Kocieniewski, D. (2012). How apple sidesteps billion in taxes. The New York Times.

Dyreng, S., Hanlon, M., \& Maydew, E. (2008). Long-rung corporate tax avoidance. The Accounting Review, 83(1), 61-82.

Ge, W., Drury, D. H., Fortin, S., Liu, F., \& Tsang, D. (2010). Value relevance of disclosed related party transactions. Advances in International Accounting, 26, 134-141.

Jones, C., Temouri, Y., \& Cobham, A. (2018). Tax haven networks and the role of the Big 4 accountancy firms. Journal of World Business, 53, 177-193.

La Porta, R., Lopez-de-Silanes, R., Shleifer, A., \& Vishny, R. (2000). Investor protection and corporate governance. Journal of Financial Economics, 58(1), 1-25.

Muhammadi, A. H., Ahmed, Z., \& Habib, A. (2016). Multinational transfer pricing of intangible assets : Indonesian tax auditors' perspectives. Asian Review of Accounting, 24(3), 313-337.

Observation \& Research of Taxation (Ortax). (2012). Pajak Rugi Triliunan dari Praktik Transfer Pricing. Retrieved from http://www.ortax.org/ortax/?mod=berita\&page=show\&id=12379\&q=\&hlm=

Organisation for Economic Co-operation and Development (OECD). (2017). OECD Work on Taxation. Retrieved from http://www.oecd.org/tax/centre-for-tax-policy-and-administration-brochure.pdf

Otoritas Jasa Keuangan (OJK). (2015). Siaran Pers: OECD dan OJK luncurkan prinsip Good Corporate Governance G20/OECD. Retrieved from https://www.ojk.go.id/id/kanal/pasar-modal/berita-dan-kegiatan/siaran-pers/Pages/OECDOJK-Luncurkan-Prinsip-Good-Corporate-Governance-G20-OECD.aspx

Rego, S. O. (2003). Tax-avoidance activities of U.S. multinational corporations. Contemporary Accounting Research, 20(4), 805-833.

Richardson, G., Taylor, G., \& Lanis, R. (2013). Determinants of transfer pricing aggressiveness: Empirical evidence from Australian firms. Journal of Contemporary Accounting \& Economics, 136-150.

Sari, D. K., Utama, S., \& Rossieta, H. (2017). Tax avoidance, related party transactions, corporate governance and the corporate cash dividend policy. Journal of Indonesian Economy and Business, 32(3), 190-208.

Utama, C. A. (2015). Penentu besaran transaksi pihak berelasi: Tata kelola, tingkat pengungkapan, dan struktur kepemilikan. Jurnal Akuntansi dan Keuangan Indonesia, 12(1).

Utama, C. A., \& Utama, S. (2014). Corporate governance, size and disclosure of related party transactions, and firm value: Indonesia evidence. International Journal of Disclosure and Governance, 11(4), 341-365.

Utama, S., Utama, C. A., \& Yuniasih, R. (2010). Related party transaction-efficient or abusive: Indonesia evidence. Asia Pacific Journal of Accounting and Finance, 1.

Waworuntu, S. R., \& Hadisaputra, R. (2016). Determinants of transfer pricing aggressiveness in Indonesia. Pertanika Journal Social Sciences \& Humanities, 24, 95-110.

Womack, B., \& Drucker, J. (2011). Google questioned by SEC over earning in low-tax countries. Bloomberb News. 